to bring to bear on that side of the question. But I have thought it worth while to recall attention to the Lexden subsidence, and to my remarks upon it.

Hartton, Cambridae, 11 Dec. 1881.

O. FISH WR.

\title{
JUKES AND THE SUPPOSED LAURENTIAN ROCKS IN DONEGAL,
} IRELAND.

Sin,-From a letter that I have received, it would appear that some question my statement in the letter on the "Lower Palæozoic Rocks of Wexford," that Jukes first suggested the possibility of there being Laurentian rocks in Donegal. I find that new men in new countries, who do not take the trouble to learn what others have previously done, often bring forward "new discoveries," which, although new to them, are well known and old to those acquainted with the country. The present question appears to be a case in point. It must be about twenty years ago when Jukes first suggested that some of the rocks in Donegal were possibly of Laurentian age, and when King, of Galway, made a similar statement in reference to the Connemara rocks. At all events, when I was sent to the West Galway district about the year 1863 , I was specially instructed on this point, because it was supposed that possibly Laurentian rocks might be found in Galway, Mayo, and Donegal. While working in North-west Connaught from 1863 to 1871, I have over and over again discussed the probability of Laurentian existing in the above-named counties with Jukes, King, Melville, Harkness, and all other geologists who visited me during those years, among whom was Prof. Hull. I suspect that even Sir R. I. Murchison, in the papers published in the GuoL. MAG. about that time, also mentions Mr. Jukes' suggestion as to the Laurentian age of some of the Donegal rock, but I cannot here refer to those papers. I therefore believe that I am quite justified in stating as I have done in the first chapter of the "Geology of Ireland," and in my late letter to the Geol. Mag., that any credit due is due to Prof. Jukes, until some one works out the question in detail; which has still to be done. At present even the age of the associated rocks with those suggested to be Laurentians is uncertain. They may be of the same age as those at Creggaunbaun, south of Clew Bay, which have been proved by Syme to be Upper Silurians; or they may be Cambro-Siluriaus; or in part they may be, as suggested by me in the paper read before the Royal Irish Academy, "On supposed Cambrians in Cos. Tyrone and Mayo," Cambrians; or, as does not appear improbable, if the statements made in reference to the Donegal rocks are correct, all the rocks of the country may belong to one sequence, the supposed Laurentians being a portion that is more metamorphosed than the rest; and as in many other metamorphic regions, brought down by a fault or faults into a juxtaposition with less altered rocks.

The latter suggestion is a very natural one, when we consider that on account of a similar position of rocks, a portion of the rocks of West Galway are said to be of Laurentian age. Now, in West 
Galway the geological age of the rocks is quite plain to those who will take the trouble to carefully work them out in detail; some of these rocks are excessively metamorphosed, in places being altered into granite, yet these granites can be traced into gneiss, and from that through schist and the "submetamorphic rocks" into rocks that contain fossils similar, according to Baily, to those characteristic of the Llandeilo rocks. Yet now we are told that the extremely metamorphosed portion of these rocks "are probably of Laurentian age." In one of the papers previously referred to, Sir R. I. Murchison made a somewhat similar statement, but in a subsequent paper he retracted it.

Ovoca, Dec. 8th, 1881 .

G. H. Kinahan.

"MONTALBAN" ROCKS IN SCOTLAND.

Sir,-In the published account of the very interesting and important address delivered before the Geological Society on Nov. 16th, by Dr. Sterry Hunt, "On the Eozoic Rocks of Europe as compared with those of North America," it is stated that the "Pebidian of Hicks includes both the Huronian and the Montalban, to which latter belong, according to the speaker, certain gneisses and micaschists both in Scotland and Ireland." I have repeatedly expressed the opinion that the great Pebidian formation, as at present defined in this country, will have to be divided into several distinct series, and that it is not improbable that we include in it now formations unconformable to one another. In describing the Scotch rocks (Proc. Geologists' Assoc. vol. vii. p. 20), I called special attention to a series of gneisses and mica-schists along the sides of Loch Eil, and I said that these " differ considerably from those further west, and strike from N.E. to S.W., with an average dip of about $45^{\circ}$ to the N.W. They alternate with a corrugated mica-schist and with quartzose bands, which are spotted with a greenish micaceous mineral. These I look upon as newer than the Loch Shiel series, and probably faulted down against the latter. They should probably be classed with the Pebidian rocks of Anglesea, and with others to be further referred to in the more central parts of Scotland." I showed specimens of these rocks to Dr. Hunt, and he immediately recognized their great resemblance to his Montalban series. My chief reason for including these in the Pebidian was that they are undoubtedly newer than the gneisses farther west, and that they had the general strike of the undoubted Pebidian rocks found along the Caledonian Canal. That they will, however, in time have to be separated from the latter is certain, and that they moreover occupy extensive areas in the Grampians, I have proved from careful examination. At Tyndrum, and also in many areas to the northeast and east, they are well exposed. Indeed, they may be said to be the most important series in the Grampians; hence I proposed to Dr. Sterry Hunt that they should in future be separated from the Pebidian under the distinctive name of "Grampian Series."

Herson, Dec. 1881.

Henry Higks. 